\title{
Effect of Sheet Pile Driving on Geotechnical Behavior of Adjacent Building in Sand: Numerical Study
}

\author{
A. M. Basha ${ }^{a^{*}}$, M. N. Elsiragy ${ }^{b}$ \\ ${ }^{a}$ Assistant Professor, Department of Civil Engineering, Faculty of Engineering - Kafrelshiekh University, Egypt. \\ ${ }^{b}$ Assistant Professor of Geotechnical Engineering, Department of Structural Engineering, Faculty of Engineering, October 6 \\ University, Egypt.
}

Received 11 March 2019; Accepted 10 July 2019

\begin{abstract}
Construction vibration such as sheet pile driving can produce earthborn vibrations which may be leads to problems for the supporting soils and adjacent structures. Vibrations create the stress waves traveling outward from the source through the soil and cause structural damage due to dynamic vibration induced settlement. The main aim of the present research is to study the vibration effect through sheet pile driving technique on the surrounding soil and adjacent structure. A series of plain strain finite element analysis using Plaxis 8.2 dynamic module is run to simulate the installation technique of a sheet pile unit using driving technique (hammer type). The effect of construction stages with different embedded sheet pile depth, sand relative density, and foundation distance from the driving source is also studied. The influence of hammer driving amplitude on the foundation response and excess pore water pressure are presented. The results showed that the increase of both embedment sheet pile depth and hammer efficiency can significantly produce higher excess pore water pressure and foundation settlement. The increase of sand density can also has a great effect in increasing the foundation damage of adjacent structure compared with low sand relative density. The building damage can significantly take place when the driving is closed to foundation.
\end{abstract}

Keywords: Finite Element; Sheet Pile Driving; Plaxis; Pore Pressure; Dynamic Settlement.

\section{Introduction}

Building vibrations can generate soil vibration with variation in intensity, which mainly depends upon the source of vibration. Pile driving is mainly used in many applications for geotechnical engineering (i.e. foundation support and etc. Pile-driving is installed typically by use of impact or vibratory hammers.

Ground vibrations due to pile driving are part of a complex process. Vibration is generated from the pile driver to the pile. As the pile interacts with the surrounding soil, vibrations are transferred at the pile-soil interface. The vibration propagates through the ground and interacts with structures, both above ground and underground. The vibration continues into the structure where it may disturb occupants and/or damage the structure.

The vibration waves may cause potential damage of existing building induced by vibration source. More specifically, these vibrations can cause ground settlements and deformations that may lead to differential settlements of foundations. In case of vibratory sheet piling, generation and dissipation of excess pore pressure occurs simultaneously. It has been found that the interim drainage results in a significant decrease in pore pressure generation.

\footnotetext{
*Corresponding author: ealibasha@eng.kfs.edu.eg; ealibasha@yahoo.com
} 
Sassa and Sekiguchi (1999) executed model tests on the development of excess pore pressure in the seabed. The tests are performed by placing a small scale wave tank in a geo-centrifuge [1].

During the test the wave loading is constant. In the test generation and dissipation of excess pore pressure occurs simultaneously. The test shows that the excess pore pressure first increases. At this stage the generation of pore pressure is in excess of the dissipation. After some time the excess pore pressure decreases. This indicates that the generation of excess pore pressure is decreasing. Two mechanisms can be held responsible for this effect. The first is the densification of the sand due to the dissipating water. The other effect is the change in soil fabric during densification.

The same effect is observed in the tests by Sumer et al. (1999) in a small tank at ISVA, Denmark. In the tests the development of excess pore pressure in a sandy/silty seabed due to wave loading is measured. The excess pore pressure at first rises quickly. Even complete liquefaction is observed in the test. After some time the excess pore pressure decreases. Towards the end of the test the excess pore pressure is completely vanished, although the wave loading remained constant. These model tests show that dissipation of excess pore pressure increases the resistance against liquefaction [2].

Mitchell and Dubin (1986) used a very interesting test device. In the cyclic tri-axial apparatus a column filled with sand is connected to the drainage valve. The column is used to simulate the flow resistance encountered in reality by dissipating excess pore pressure. With this device the amount of dissipation could be controlled [3]. Dissipation of excess pore pressure greatly reduces the generation of excess pore pressures. This effect is therefore to be accounted for when considering the soil behaviour during vibratory sheet piling. For large shear strain amplitudes (typically shear strain amplitudes in excess of $1 \%$ ) the positive effect becomes a negative effect. Monitoring and control of construction vibrations were studied by a number of researchers e.g. [4-9] to evaluate the different effects of vibration to prevent any possible damage.

Where most well documented papers discuss behaviour of pile under dynamic driving process, on the other hand a few researchers investigate behaviour of the sheet pile. So the dynamic behaviour of soil due to driving the sheet pile needs deep investigation to reach well understanding its effect on ground surface and adjacent building. The main objective of the present paper is to study theoretically the effect of driving technique of sheet pile at different embedded lengths, the sand density and the hammer efficiency on the induced pore water pressure. Also, the study shed the light on the optimum safe distance adjacent to the building foundation to avoid any damage due to such obtained disturbance from pile driving.

\section{Mechanism of Wave Propagation}

During process of sheet pile driving seismic waves are generated. These waves transmitted through the soil by two mechanisms. First one is the shear waves, which called S-waves, it generated along the contact surface the sheet pile with the surrounding soil due to the relative motion between the sheet pile and the surrounding soil. The sheet pile driven vertically to the soil, which produces compression waves [10-17]. The S- waves spread out from the sheet pile shaft on a conical wave front as shown in Figure 1 [18]. Second type of waves is called P-waves or compression waves. It starts at the tip of the sheet pile as shown in Figure 2 [18]. Compression waves and shear waves travel quickly from sheet pile toe and sheet pile surface, respectively outwards to the ground surface through new waves called Rayleigh waves (Rwave) as shown in Figure 2. The main factors effect on dynamic waves propagation through the soil are the sheet pile depth, the soil stiffness, the soil homogeneity, and the driving energy delivered to the sheet pile [19-23].

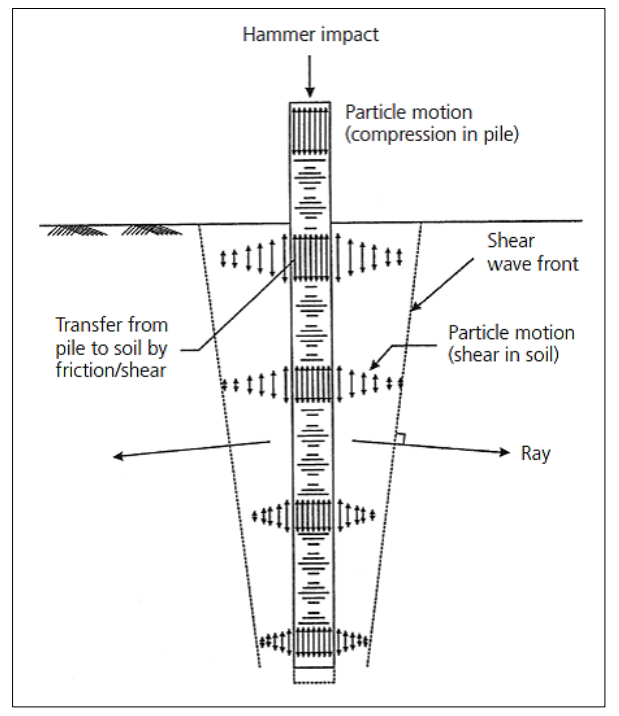

Figure 1. Generation mechanism of shear waves due to soil-pile friction [18] 


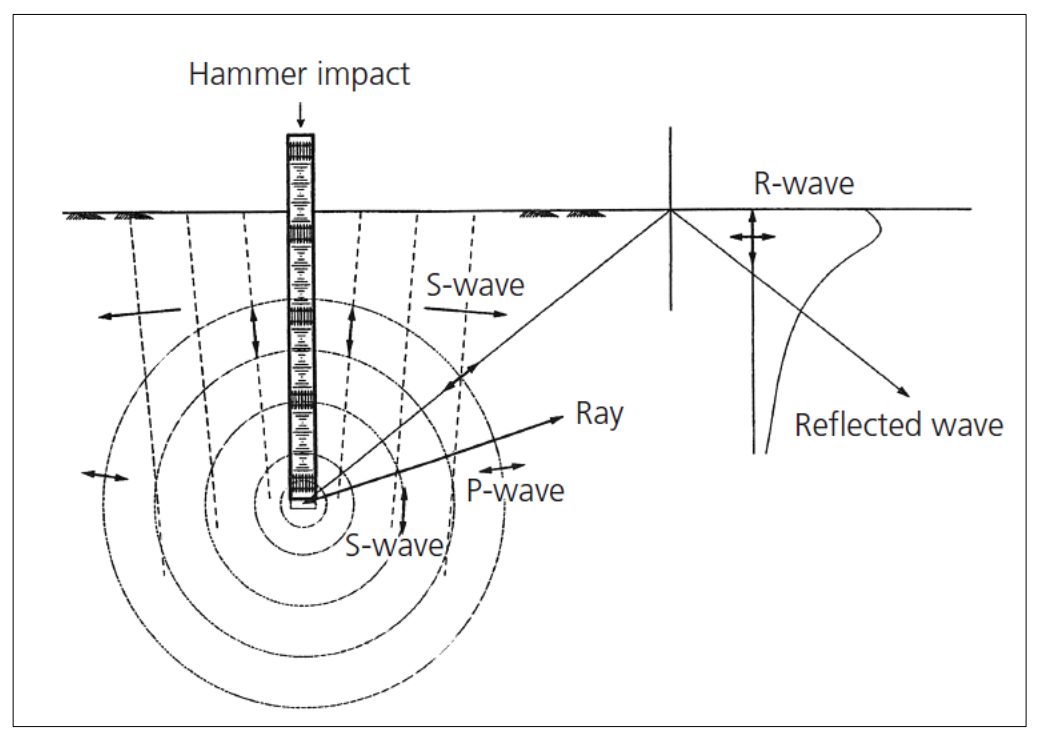

Figure 2. Combination of seismic waves resulting from impact pile driving [18]

\section{Finite Element Models and Analysis}

Finite element analyses of sheet pile driving are carried out using Plaxis 8.2 2D dynamic version. A set of general fixities to the boundary conditions of the problem are considered automatically by the Plaxis program. The Rayleigh damping is considered at vertical boundaries with $\alpha, \beta=0.01$ in order to resist the Rayleigh waves. While the plastic properties of soil are defined by using material damping, which is defined in Plaxis by Rayleigh $(\alpha$ and $\beta)$, where The Rayleigh damping is considered to be object-dependent in material data set to consider the plastic properties of soil during the dynamic analysis in Plaxis. Plaxis models for sheet pile driving are shown in Figure 3. For impact hummers, the analysis was based on three phase's plastic (staged construction) and two phases for dynamic analysis (total multipliers). The dimensions of the soil model for pile driving is taken around $50 \mathrm{~m}$ in depth and $150 \mathrm{~m}$ in width after some mesh experiments

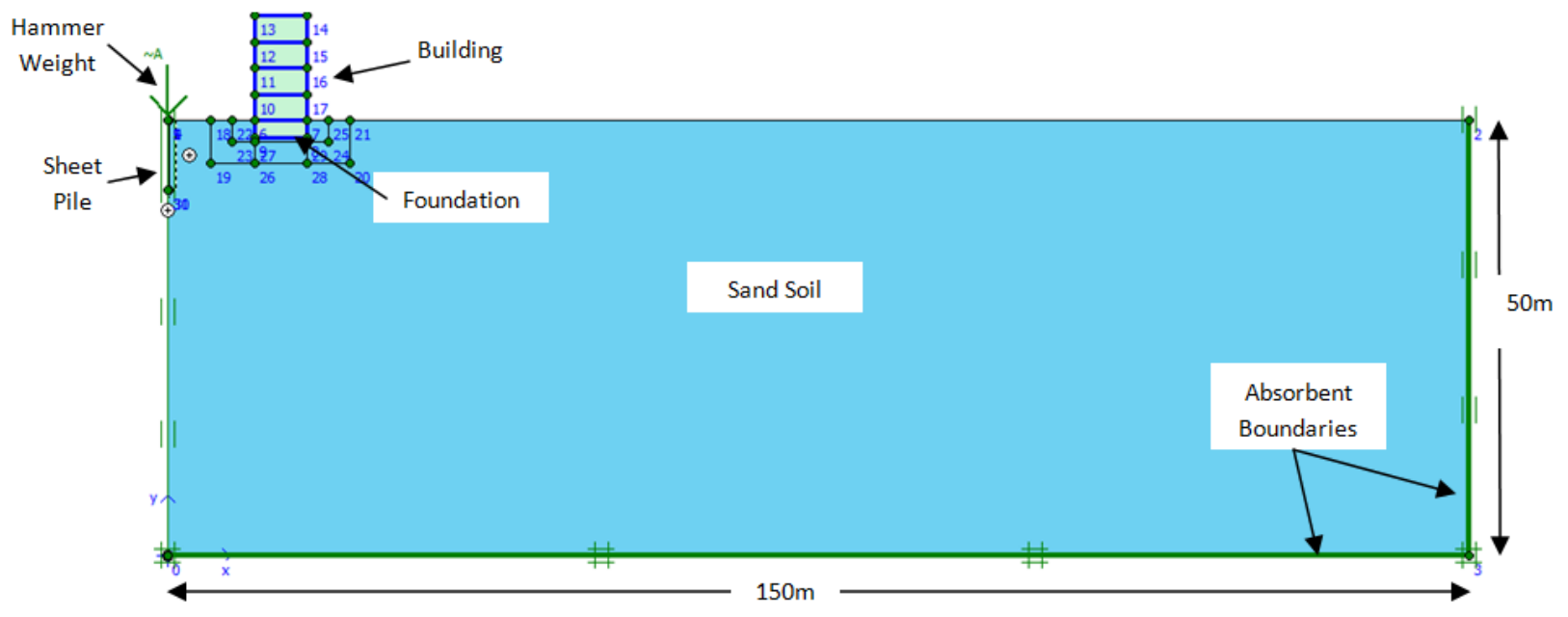

Figure 3. Plaxis numerical model for soil problem under investigation

\subsection{Description of the Model}

Different parameters used in the Plaxis model are illustrated as shown in Table 1. "Mohr Columb" undrained model is used for modelling sand. The sheet pile in Plaxis is modelled as a linear elastic non porous. The sheet pile wall is modelled using 6-noded elastic plate element with variable depth. Table 1 enlists the properties of the sheet pile wall. Figure 4 shows model deformation and Figure 5 shows the distribution of excess pore water pressure. 


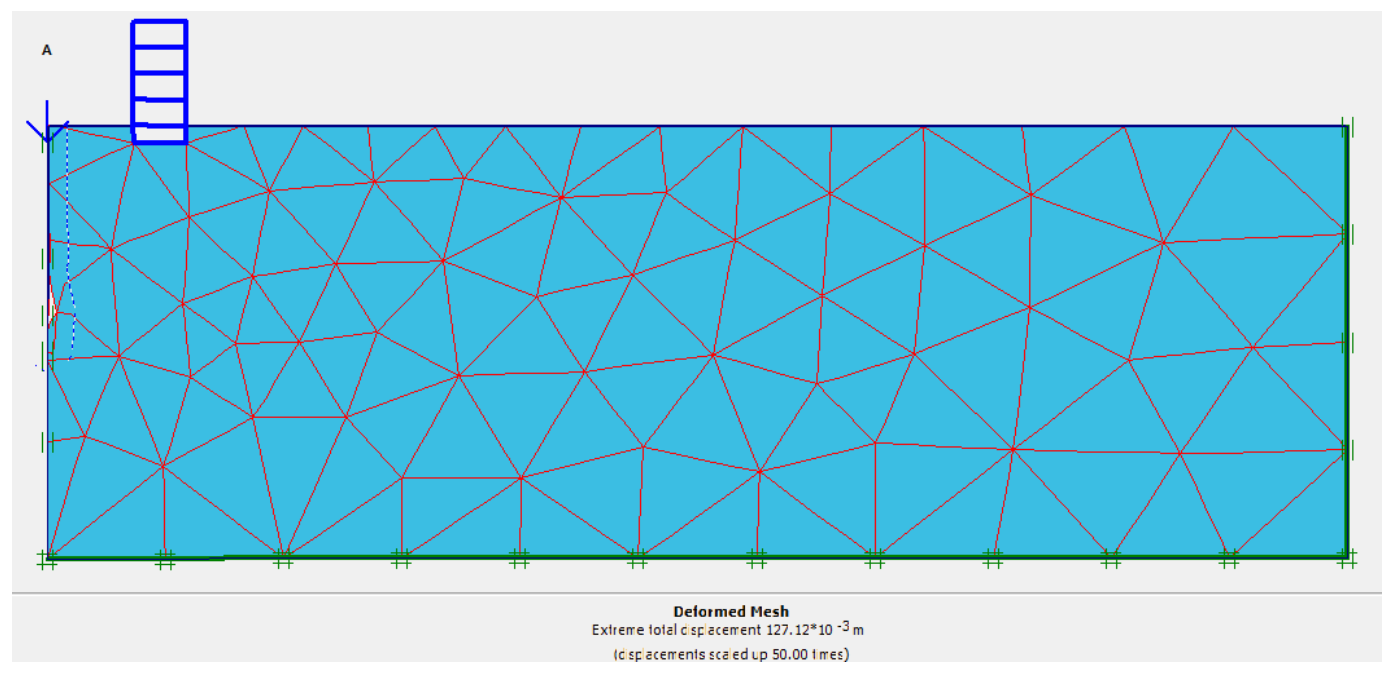

Figure 4. The results of Plaxis 2D analysis (total displacement)

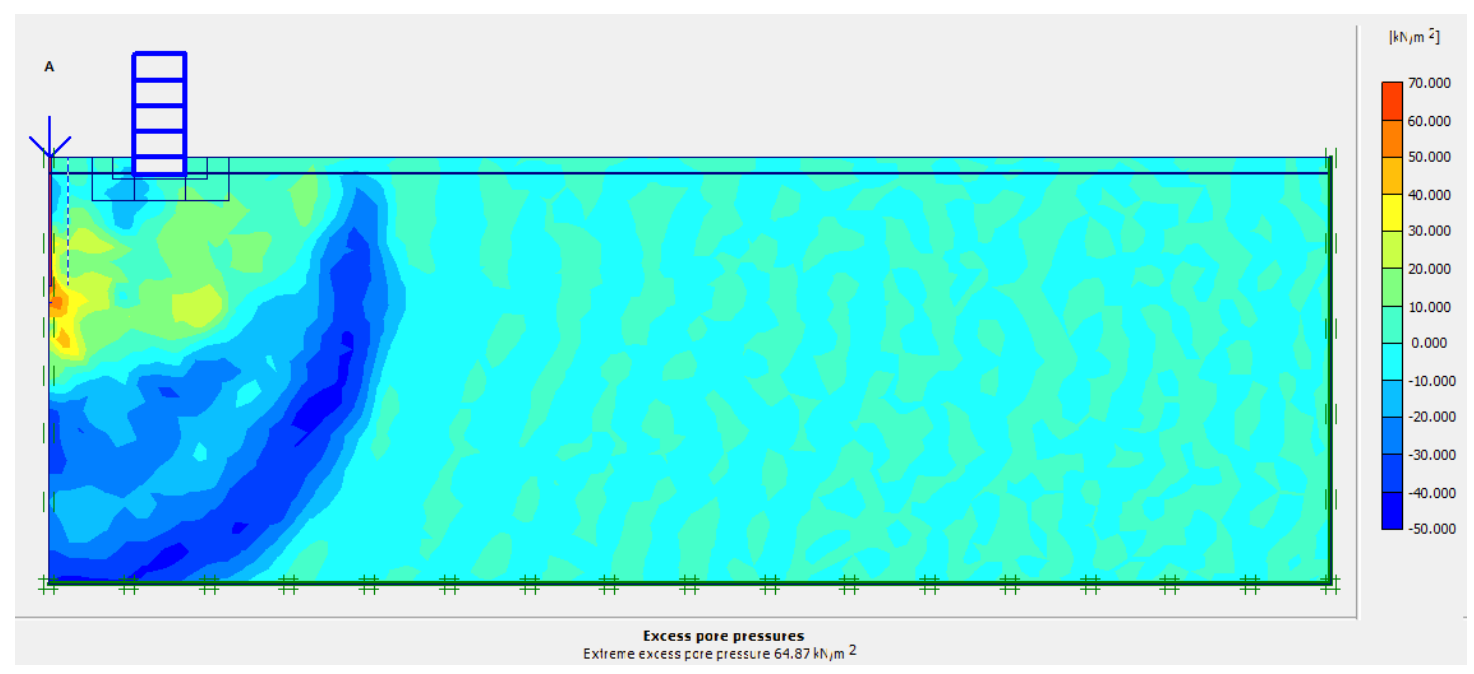

Figure 5. The excess pore water pressure

\subsection{Studied Parameters}

In this research the parameters are varied to evaluate their effects on the soil response under the effect of pile driving. Table 2 shows a series of the studied models that were run for the problem under investigation. Nine runs were carried out in order to investigate the effect of different parameters on the surrounding soil. In Table 3 the data of the adjacent building are summarized according to the manual user of Plaxis programme

Table 1. The different parameters used in the models in this research

\begin{tabular}{|c|c|c|c|c|c|c|}
\hline Parameter & Symbol & Sand 1 & Sand 2 & Sand 3 & Steel Sheet Pile & Units \\
\hline Unit weight above pheratic line & $\gamma_{\text {unsat }}$ & 17 & 18 & 20 & 72 & $\mathrm{kN} / \mathrm{m}^{3}$ \\
\hline Unit weight below pheratic line & $\gamma_{\mathrm{sat}}$ & 19 & 20 & 22 & - & $\mathrm{kN} / \mathrm{m}^{3}$ \\
\hline Young's modulus & $\mathrm{E}_{\text {ref }}$ & 20000 & 33000 & 40000 & $2 \times 10^{5}$ & $\mathrm{kN} / \mathrm{m}^{2}$ \\
\hline Oedometer modulus & $E_{\text {oed }}$ & 20000 & 33000 & 40000 & - & $\mathrm{kN} / \mathrm{m}^{2}$ \\
\hline Power & $\mathrm{m}$ & 0.5 & 0.5 & 0.5 & - & - \\
\hline Unloading modulus & $\mathrm{E}_{\mathrm{ur}}$ & 75000 & 99000 & 120000 & - & $\mathrm{kN} / \mathrm{m}^{2}$ \\
\hline Poisson's ratio & $v$ & 0.3 & 0.33 & 0.35 & 0.15 & - \\
\hline Friction angle & $\varnothing$ & 30 & 35 & 45 & - & 。 \\
\hline Dilatancy angle & $\psi$ & 0.0 & 0.0 & 0.0 & - & 。 \\
\hline Interface strength reduction & $\mathrm{R}_{\text {inter }}$ & 0.67 & 0.67 & 0.67 & - & - \\
\hline Bending stiffness & EI & - & - & ----- & $2.3 \times 10^{4}$ & $\mathrm{kN} \cdot \mathrm{m}^{2} / \mathrm{m}$ \\
\hline
\end{tabular}


Table 2. Summary of the studied series under investigation

\begin{tabular}{lc}
\hline Constant parameter & Variable parameter \\
\hline $\begin{array}{l}\text { Sandy soil with } \mathrm{E}=33000 \mathrm{kN} / \mathrm{m}^{2} \text {, hammer weight } 10 \mathrm{ton} \text {, distance of the building from the driving source } \\
10 \mathrm{~m} \text {, building width } 6 \mathrm{~m} .\end{array}$ & $\mathrm{L}_{\text {pile }}=20,15,8 \mathrm{~m}$ \\
Sandy soil with $\mathrm{E}=33000 \mathrm{kN} / \mathrm{m}^{2}$, hammer weight $10 \mathrm{ton}$, building width $8 \mathrm{~m}, \mathrm{~L}_{\text {pile }} 6 \mathrm{~m}$ & $\begin{array}{l}\text { Distance of the building from } \\
\text { the driving source }=5,10 \mathrm{~m} .\end{array}$ \\
hammer weight 10 ton, distance of the building from the driving source $5 \mathrm{~m}$, building width $8 \mathrm{~m}, \mathrm{~L}_{\text {pile }} 6 \mathrm{~m} \quad \mathrm{E}=20000,33000,40000 \mathrm{kN} / \mathrm{m}^{2}$ &
\end{tabular}

Table 3. Material properties of the building (plate properties)

\begin{tabular}{cccc}
\hline Parameter & Name & Floors/walls & Units \\
\hline Material model & Model & Elastic & -- \\
Normal stiffness & EA & 5.106 & $\mathrm{kN} / \mathrm{m}$ \\
Flexural rigidity & EI & 9000 & $\mathrm{kN} / \mathrm{m}^{2} / \mathrm{m}$ \\
Weight & w & 5 & $\mathrm{kN} / \mathrm{m} / \mathrm{m}$ \\
Poisson's ratio & $\mathrm{v}$ & 0.0 & -- \\
Rayleigh dampers & $\alpha$ and $\beta$ & 0.01 & -- \\
\hline
\end{tabular}

\section{Results and Discussions}

\subsection{Effect of Sheet Pile Embedment Lengths on Pore Pressure and Soil Settlement}

It has been found that the ground vibration due to pile driving generate from pile toe according to [8], the energy transmission efficacy correctly reflects the vibration emission from the pile to the surrounding soil after [8, 10]. Therefore the effects of pile length on the vibration amplitude and pore pressure consider an important parameter to be discussed. Trial 1 based on pile length of $20 \mathrm{~m}$ to illustrate the effect of the maximum embedment length. The pore pressure and soil settlement are taken on different places on the model (at the ground surface, at depth of 2,5,7m in the close corner of the building to the driving source $10 \mathrm{~m}$ horizontally, in the middle of the building $13 \mathrm{~m}$ horizontally and the other corner of the building $16 \mathrm{~m}$ horizontally respectively).

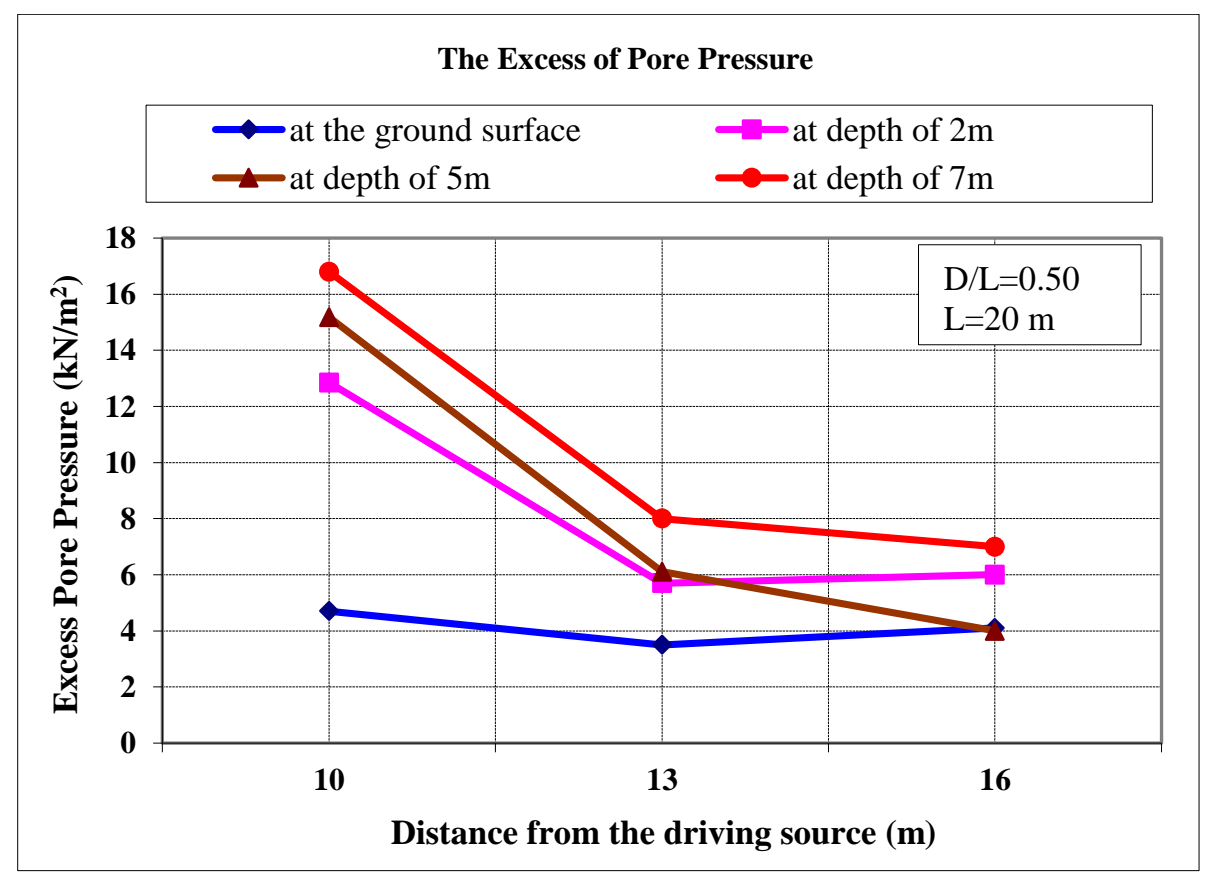

Figure 6. The pore water pressure values due to driving pile at length of $20 \mathrm{~m}$ and $\mathrm{D} / \mathrm{L}=0.5$ 
Figure 6 shows the pore pressure values at ratio of $\mathrm{D} / \mathrm{L}=0.5$ where $\mathrm{L}$ is the pile length and $\mathrm{D}$ is the distance of the building from the driving source. It can be noticed that the pore pressure is increased by getting close to the pile toe and the start to be decreased at the ground surface and by getting far horizontally from the pile driving. Trial \# 2 at pile length of $15 \mathrm{~m}$ and at the same places of measurements with $\mathrm{D} / \mathrm{L}=0.67$, it has found that the same trend is given but with higher values of pore pressure as shown in Figure 7 . As it is expected in trial \# 3 for $\mathrm{D} / \mathrm{L}=1.25$, the values of pore pressure is increased by almost the double compared to trial \#2, as shown in Figure 8.

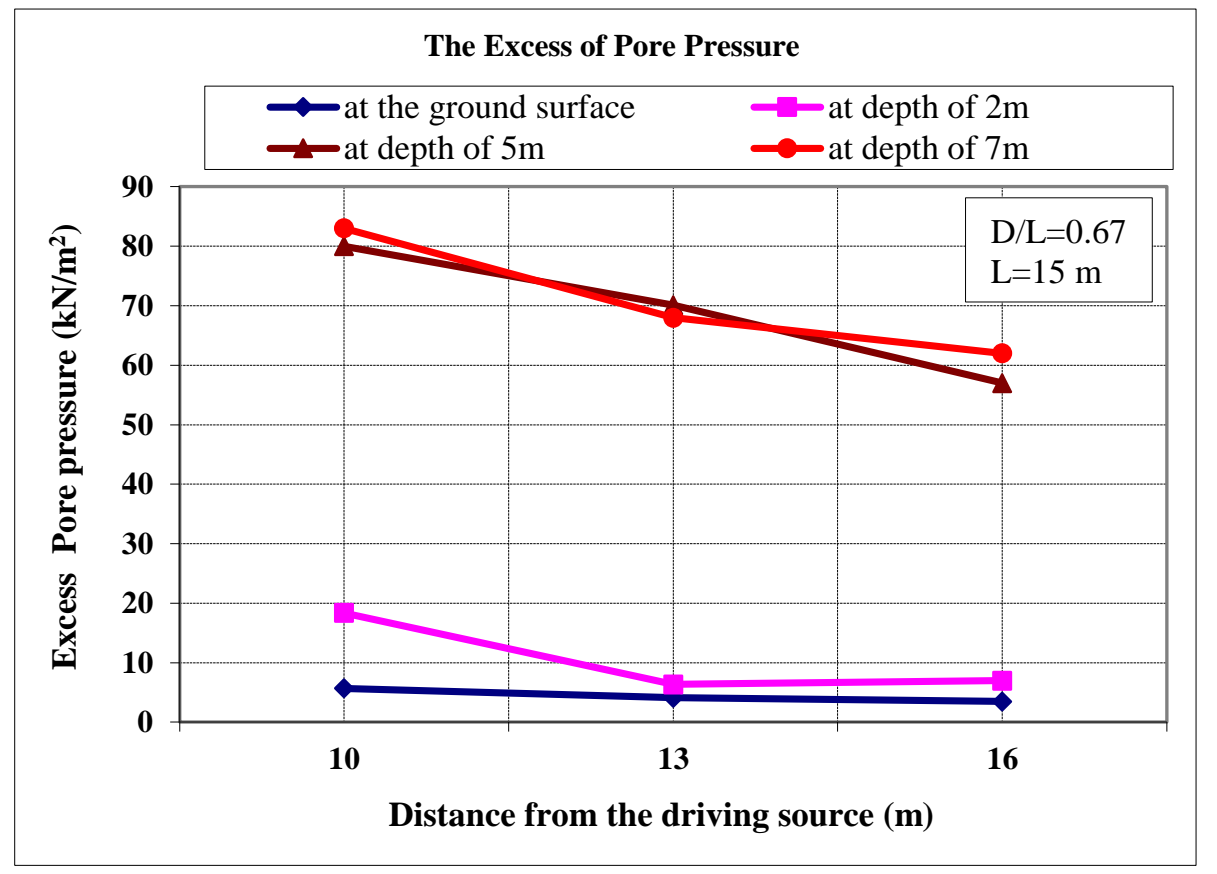

Figure 7. The pore water pressure values due to driving pile at length of $15 \mathrm{~m}$ and $\mathrm{D} / \mathrm{L}=\mathbf{0 . 6 7}$

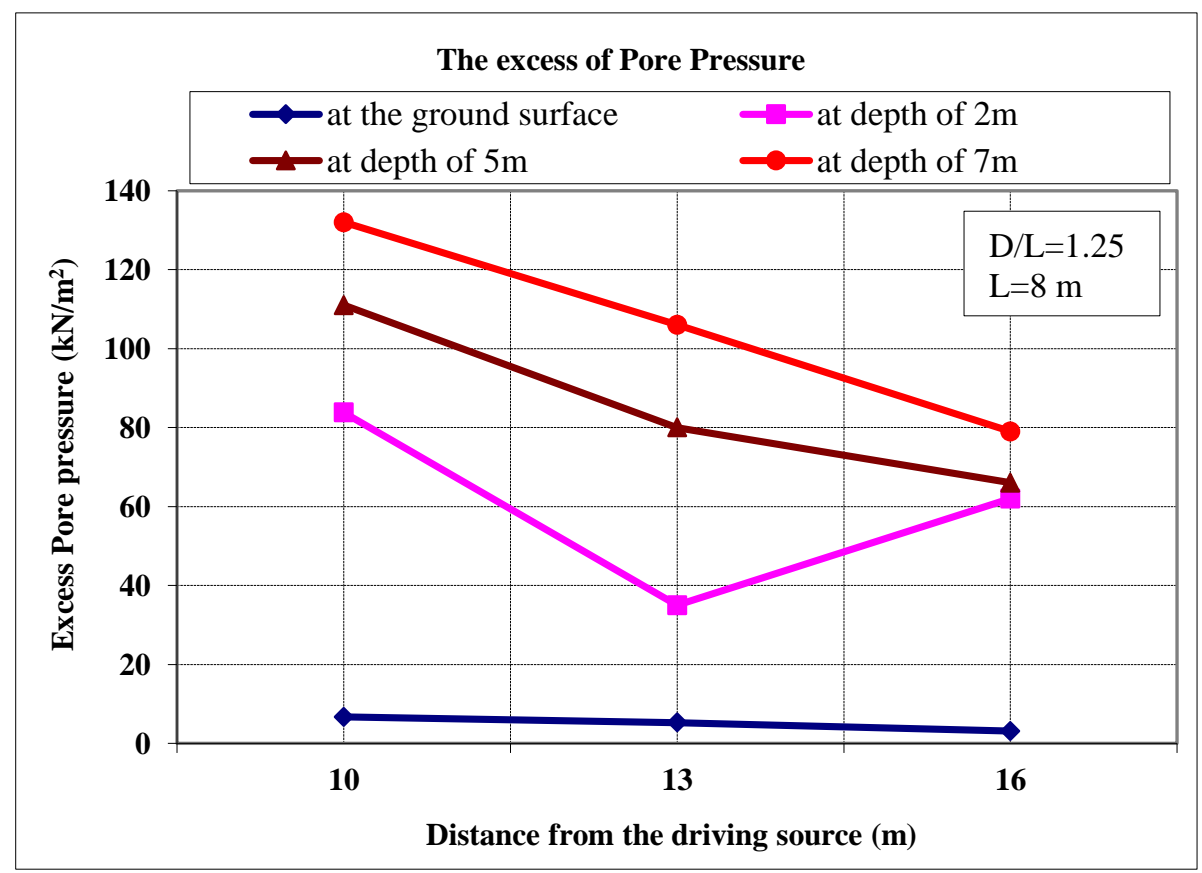

Figure 8. The pore water pressure values due to driving pile at length of $8 \mathrm{~m}$ and $\mathrm{D} / \mathrm{L}=1.25$

For the same condition soil displacement is measured typically in the same places to express soil settlement. It is found that for relatively high density of sand soil settlement considers to be low. Figures 9 to 11 show the values of soil displacement for different cases of pile driving (at different embedment lengths). It can be seen that soil displacement increases by increasing the pile length close to pile toe. At $10 \mathrm{~m}$ horizontally from the driving source at the ground surface there is no clear effect of driving energy on settlement values; however there are other parameters could be harmful to the building. Soil settlement is higher than the ground surface and it could be harmful to underground structures, tunnels, and water or gas pipe lines. 


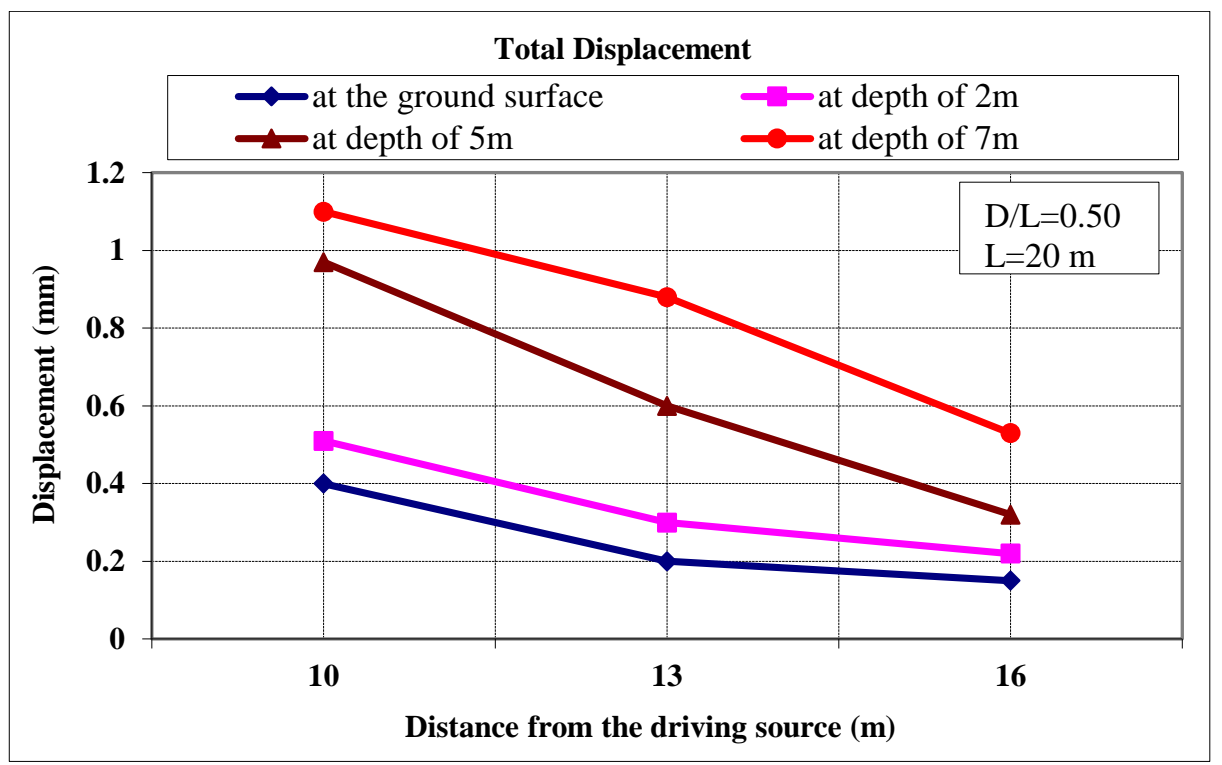

Figure 9. The soil settlement values due to driving sheet pile at length of $20 \mathrm{~m}$ and $\mathrm{D} / \mathrm{L}=0.5$

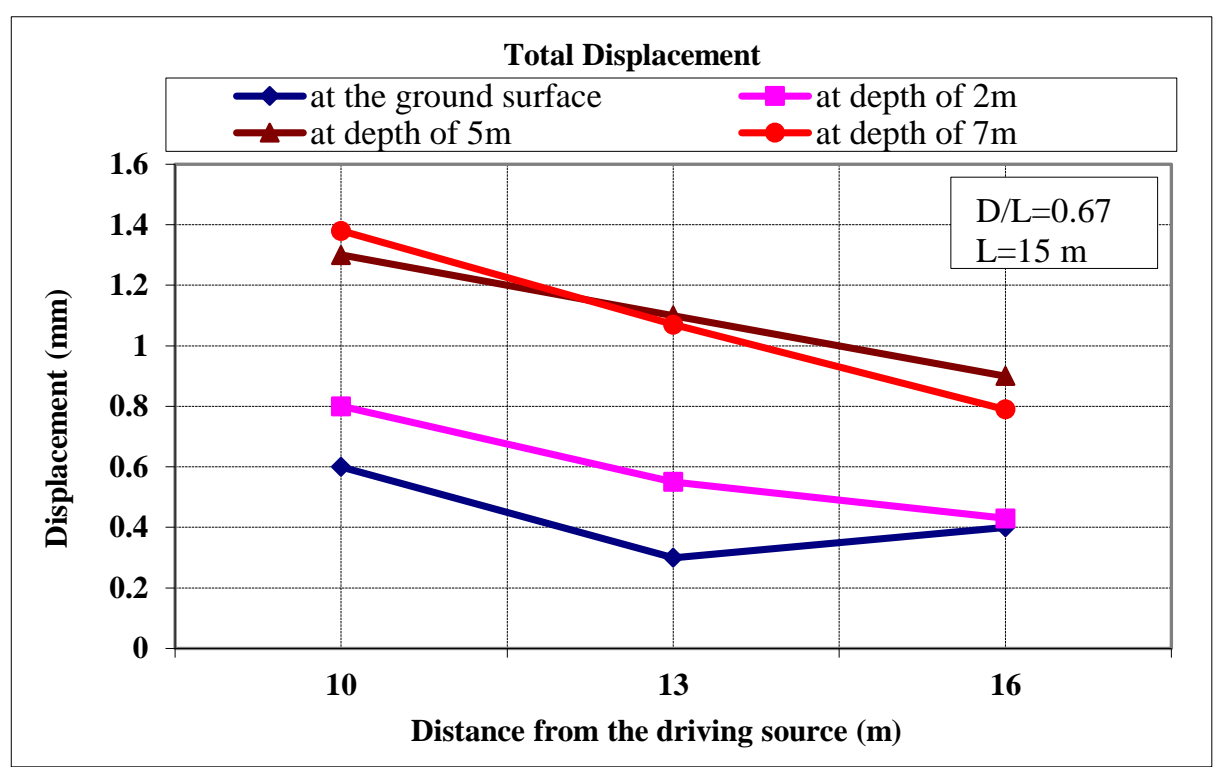

Figure 10. The soil settlement values due to driving sheet pile at length of $15 \mathrm{~m}$ and $\mathrm{D} / \mathrm{L}=0.67$

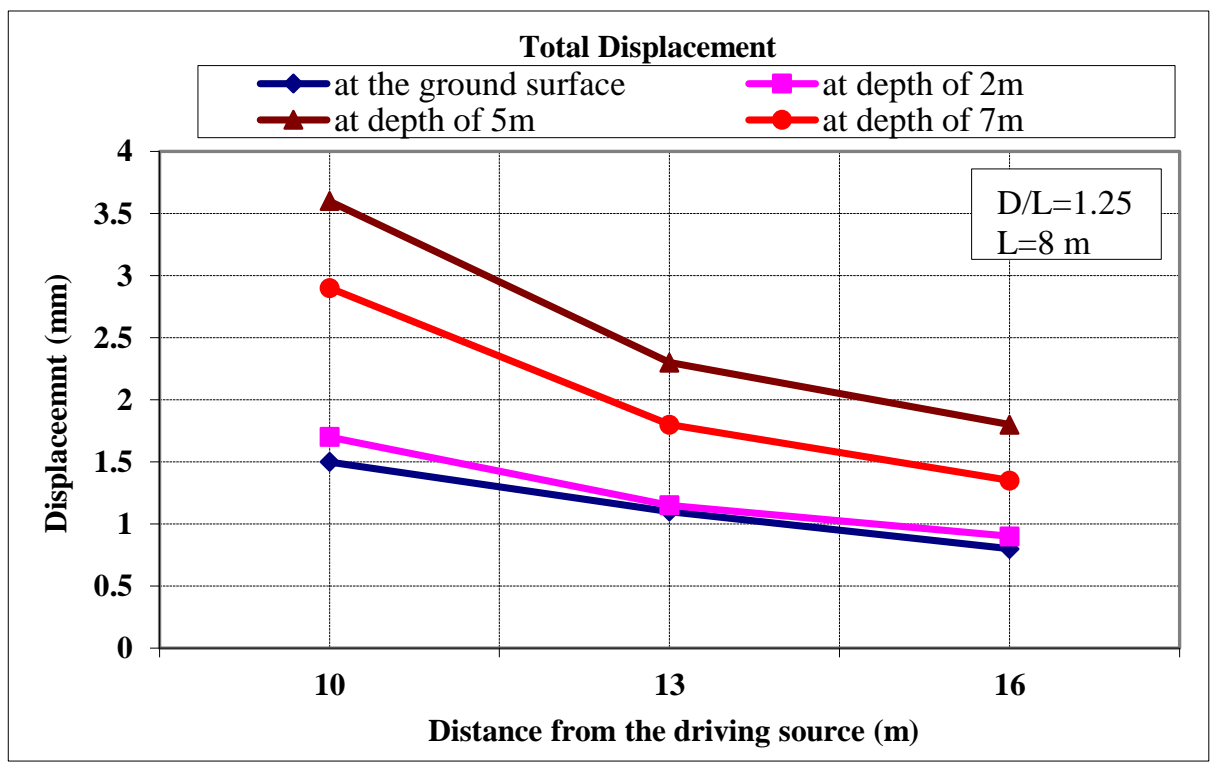

Figure 11. The soil settlement values due to driving sheet pile at length of $8 \mathrm{~m}$ and $\mathrm{D} / \mathrm{L}=\mathbf{1 . 2 5}$ 
4.2. Effect of Different Distances of the Adjacent Building from the Driving Source on Pore Pressure and Soil Settlement

The main goal of this research is to know the safe limits of pile driving procurement to avoid any possible damage to the adjacent building. Focus will be on the effective distance of the adjacent structure which cannot be exceeded. Different distances are used to represent the adjacent building to sheet pile driving and expressed by the term of (W) the other parameters are constant. It is known that the great values of vibration amplitude is close to the driving source and start to attenuate by getting far from the driving source after [10]. To reach the ultimate case a $6 \mathrm{~m}$ sheet pile $(\mathrm{L}=6)$ is used for giving the higher possible vibration amplitude. The first trial for $5 \mathrm{~m}$ distance from the driving source (W=5) and the ratio $\mathrm{W} / \mathrm{L}=0.83$. It can be seen that pore pressure values increased closed to the driving source and exceeded the damage criteria and would cause significant damage to the building. Fig. 11 shows the pore pressure values at $\mathrm{W} / \mathrm{L}=$ 0.83 which consider unsafe ratio and the design engineer should avoid achieving that ratio to protect the adjacent buildings. Fig. 12 shows the results of pore pressure measurements at $10 \mathrm{~m}$ distance from the driving source with $(\mathrm{W} / \mathrm{L}=$ 1.67). It is noticed that and confirmed by the previous analysis by getting far from the source of vibration the values of pore pressure start to be reduced by soil damping coefficient. For safety distance against vibration it is recommended to be in the range of 20 to $25 \mathrm{~m}$ away from the driving source. Sometimes there are no so many options to reach that safety distance therefore other methods for protection buildings is developed such as wave barriers.

Soil settlement is investigated at the same conditions for a building at $5 \mathrm{~m}$ from the driving source. Settlement recorded a high values which are very hazard to the adjacent building and go beyond the limits set by the Egyptian code. It can be illustrated that it will not be accepted to process a sheet pile driving at $5 \mathrm{~m}$ distance from the nearest building without the needed precautions. Differential settlement is very important indicator to the damage on the buildings, due to soil densification by the vibration and it is already known that the vibration amplitude decreased by the distance from the vibration source that will produce different values of soil densification along the distance from the vibration source which leads to differential settlement. Another effect of pile driving on the building is the distortion of the elements of the building itself, the building is vibrated directly due to the wave of vibration and will lead to increase in straining action of the structure elements. Displacement of the top of the building is measured by Plaxis and it shows different values in the both corners of the building.

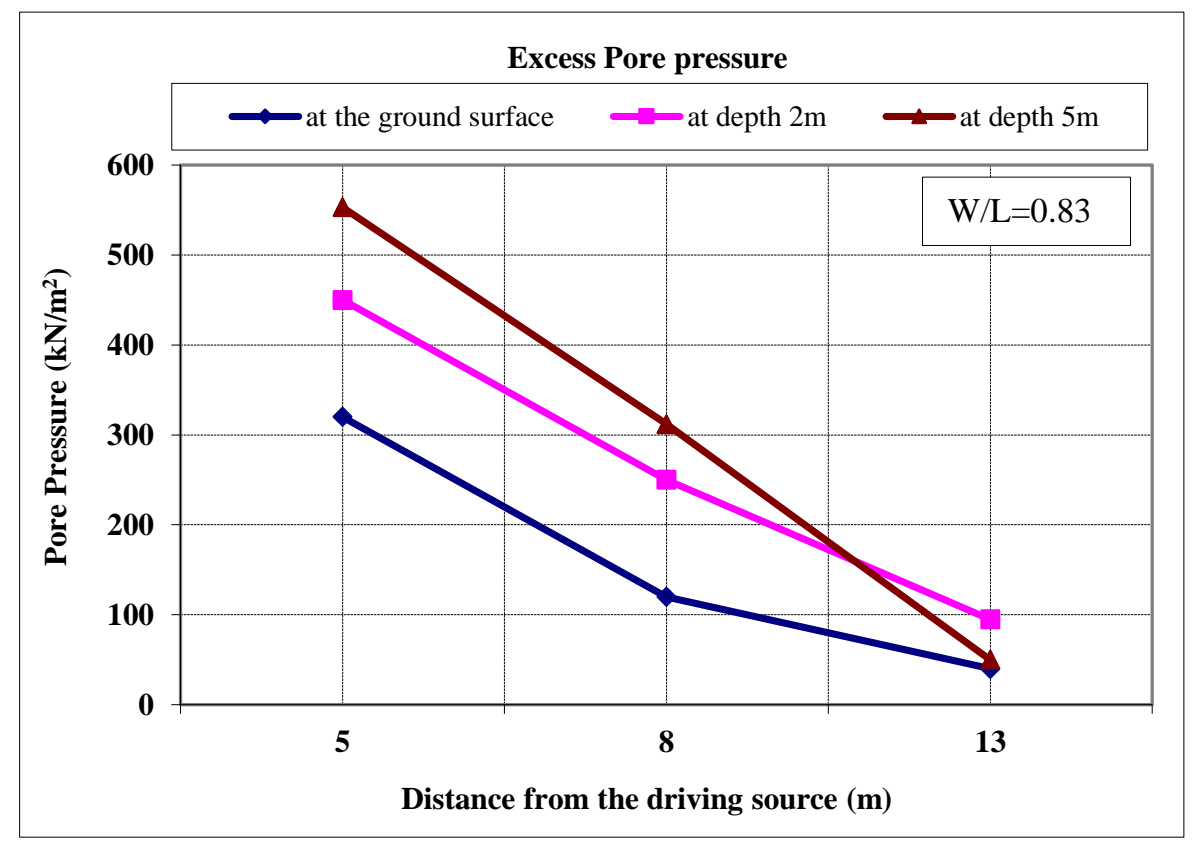

Figure 11. The pore pressure values due to driving pile and $W / L=0.83$ 


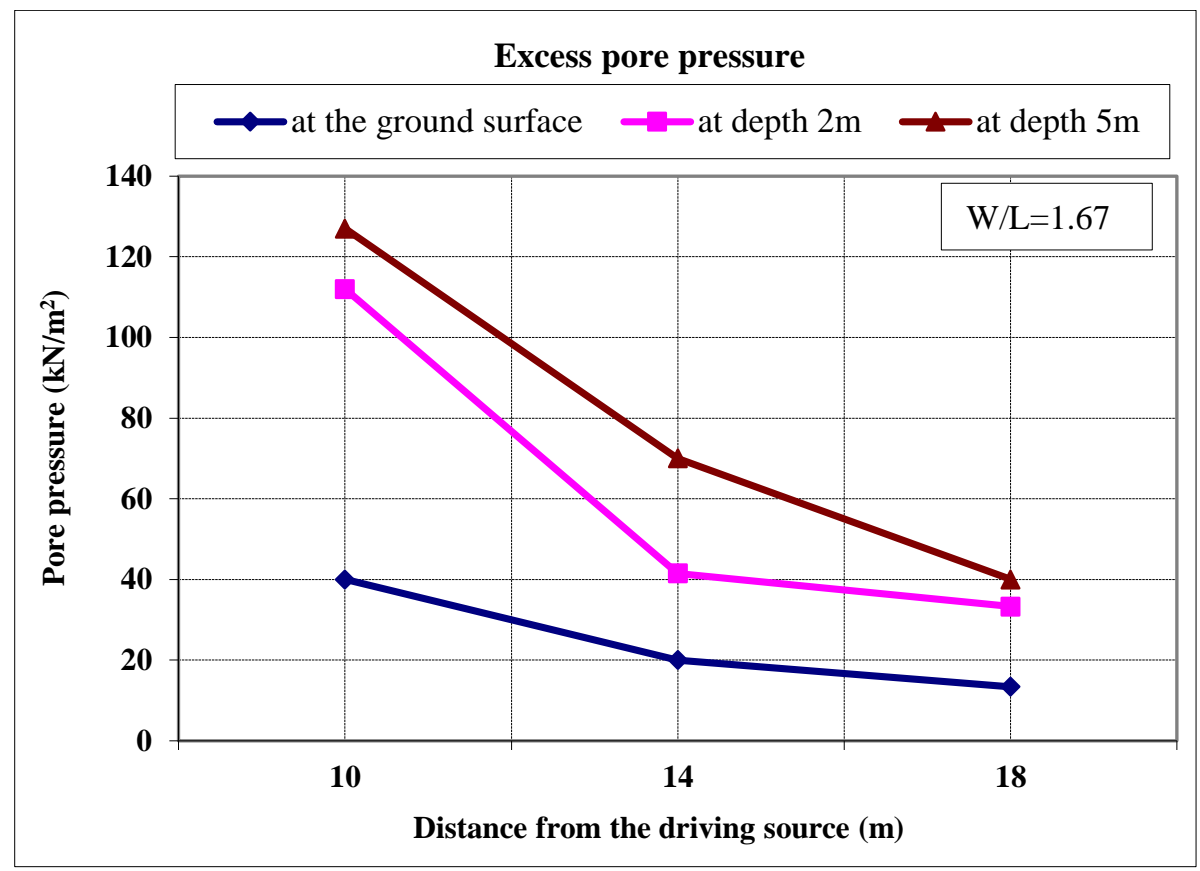

Figure 12. The pore pressure values due to driving pile and $W / L=1.67$

That distortion of the buildings elements depends mostly on the wave length and the width of the building according to [10]. Figure 13 shows soil displacement and the building displacement at the top of it. It can be seen that soil displacement is high close to the building foundation which cause failure due to differential settlement beneath the foundation. The angular distortion of the top of the building in $\mathrm{mm}$ is $10 / 5.6=1.78$ and it obviously a great value for an $8 \mathrm{~m}$ width building.

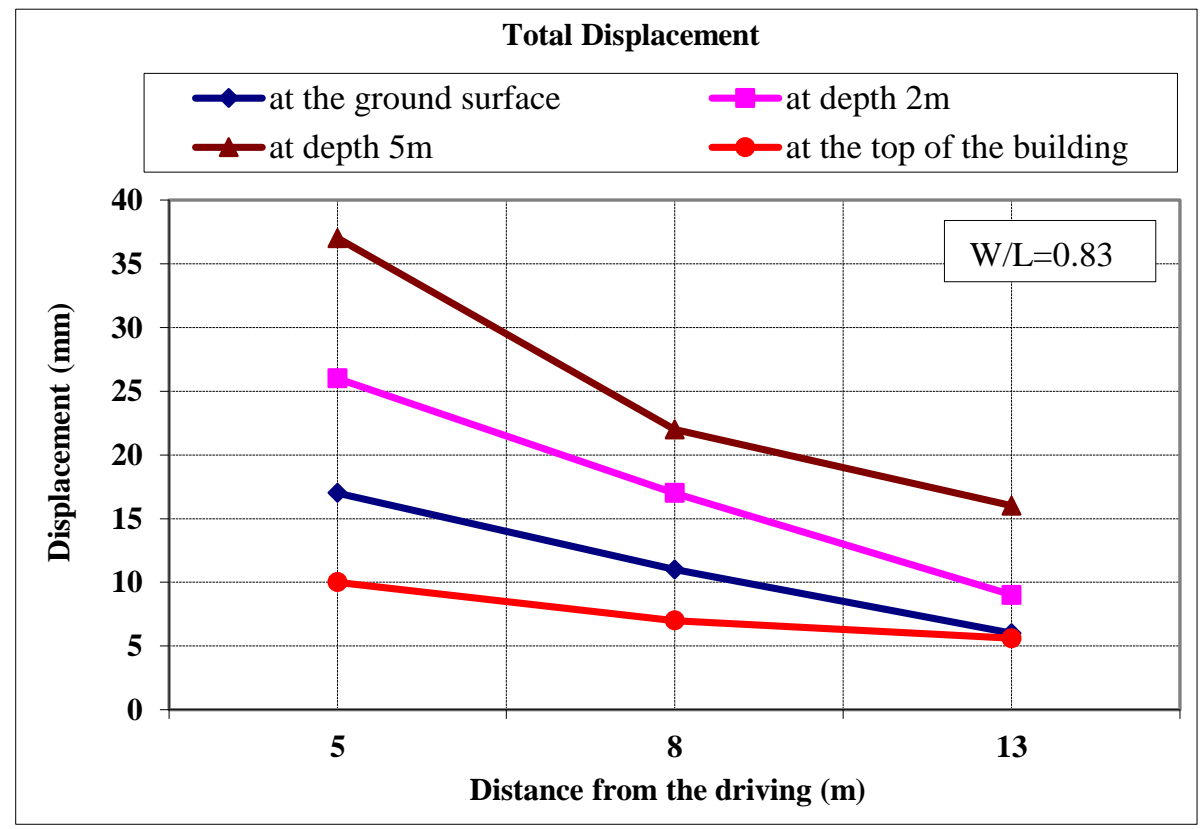

Figure 13. The soil settlement values and building displacement due to driving sheet pile at length of $6 \mathrm{~m}$ and $\mathrm{W} / \mathrm{L}=0.83$

\subsection{Effect of Different Sand Stiffnesses on Pore Pressure and Soil Settlement}

Soil stiffness is very important parameter controlling the vibration amplitude because of the shape of particles and cohesion or friction between the soils particles, show how the waves of vibration propagate through the soil. Dense and hard soil produce high vibration amplitude compared with soft or loose soils according to [11]. Increasing in vibration amplitude leads to an increscent in excess pore pressure values. It can be seen that by increasing soil stiffness the pore pressure increase see Figure 14, which indicate that using driving piles in dense soil can increase the possibility of damage on adjacent buildings. Pore pressure is measured for three different soil stiffness at $\mathrm{E}=20000,33000,40000$ $\mathrm{kN} / \mathrm{m}^{2}$ at the foundation level ( $2 \mathrm{~m}$ depth). It is noticed that the excess of pore pressure at soil stiffness of 33000 and 
$40000 \mathrm{kN} / \mathrm{m}^{2}$ is relatively close and gives the same trend especially beyond about $20 \mathrm{~m}$ from the driving source where the values of Pore pressure start to decay. For pore pressure values at soil stiffness of $\mathrm{E}=20000 \mathrm{kN} / \mathrm{m}^{2}$ it can be seen that the low values of pore pressure compared with the other cases of high soil stiffness. At $25 \mathrm{~m}$ and more the pore pressure values reach its minimum and there will be any possible hazard on buildings at that distance.

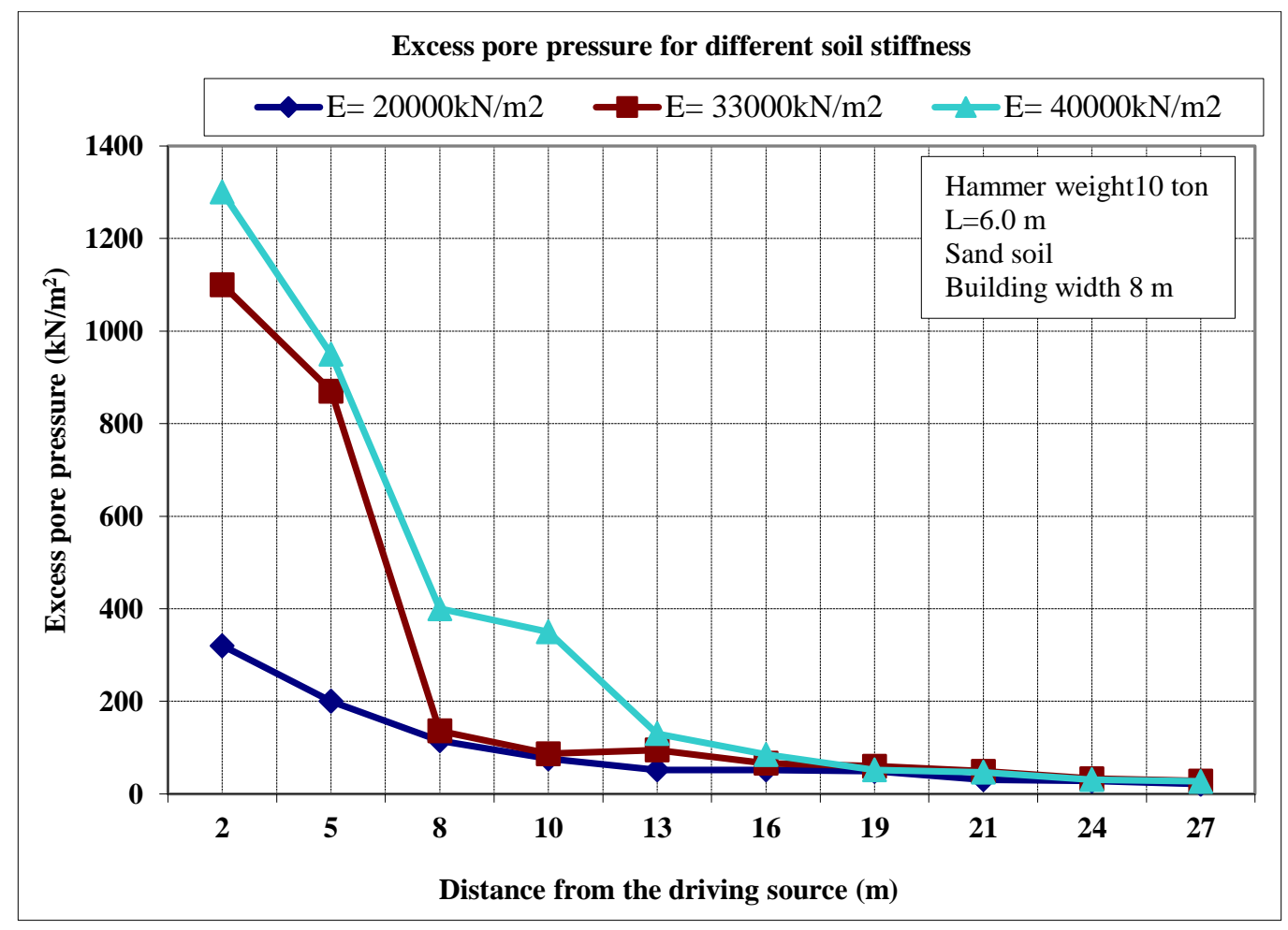

Figure 14. The excess of pore pressure due to driving sheet pile at different soil stiffness

On the other hand soil settlement increase in case of dense soil due to enlarge of densification by the great vibration amplitude, which leads to differential settlement. Figure 15 shows soil settlement values at different soil stiffness, it can be seen that at soil stiffness of $40000 \mathrm{kN} / \mathrm{m}^{2}$ the soil settlement increase especially in the range $5 \mathrm{~m}$ from the driving source. Driving piles should not be processed at a distance less than $5 \mathrm{~m}$.

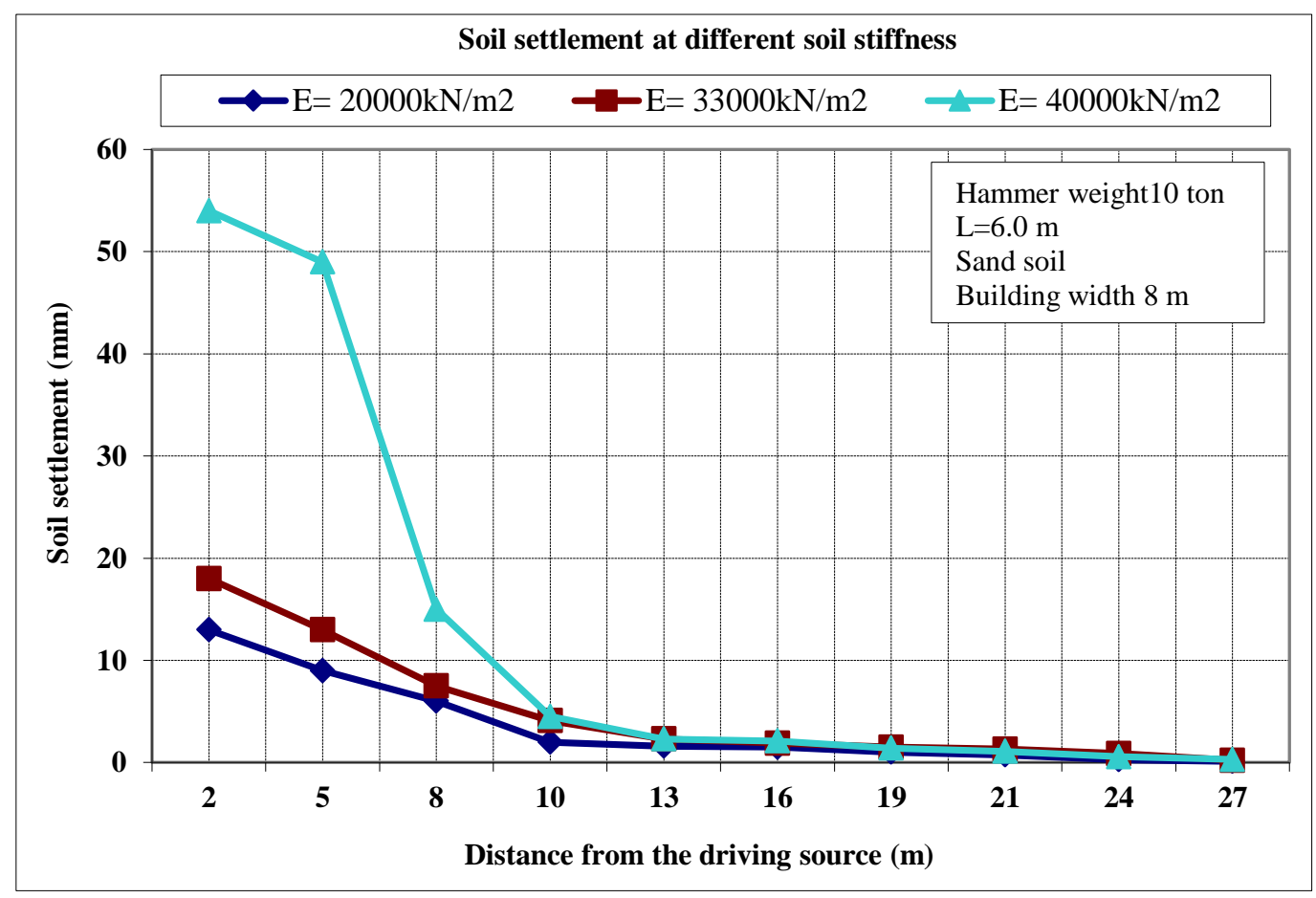

Figure 15. The excess of pore pressure due to driving sheet pile at different soil stiffness 


\section{Conclusions}

Effect of the pile driving on the excess of pore pressure and adjacent foundation response to born vibration are investigated using Finite Element Analysis. Based on the data and the results of the analysis presented in this paper, the following main conclusions can be drawn:

- Pore water pressure increased close to the pile toe and decreased by getting far from the vibration source.

- The ratio of $\mathrm{D} / \mathrm{L}$ gives the optimum values and the safe criteria when it doesn't exceeded 0.5.

- For the safe distance of buildings against the damage due to excess pore pressure is beyond $25 \mathrm{~m}$ and with ratio $\mathrm{W} / \mathrm{L}$ more than 2.

- Soil settlement reaches the highest values close to the driving source and the possible hazard increase in the range of $5 \mathrm{~m}$ from the driving source.

- Increasing of soil stiffness increase the vibration amplitude which leads to an increase in pore pressure and soil settlement.

\section{Conflicts of Interest}

The authors declare no conflict of interest.

\section{References}

[1] Sassa, S., and H. Sekiguchi. "Wave-Induced Liquefaction of Beds of Sand in a Centrifuge." Géotechnique 49, no. 5 (October 1999): 621-638. doi:10.1680/geot.1999.49.5.621.

[2] Sumer, B.M, J Fredsøe, S Christensen, and M.T Lind. "Sinking/floatation of Pipelines and Other Objects in Liquefied Soil under Waves." Coastal Engineering 38, no. 2 (October 1999): 53-90. doi:10.1016/s0378-3839(99)00024-1.

[3] Mitchell, Robert J., and B. Ian Dubin. "Pore Pressure Generation and Dissipation in Dense Sands under Cyclic Loading." Canadian Geotechnical Journal 23, no. 3 (August 1986): 393-398. doi:10.1139/t86-055.

[4] Wersäll, Carl, and K. Rainer Massarsch. "Soil Heave Due to Pile Driving in Clay." Sound Geotechnical Research to Practice (February 25, 2013). doi:10.1061/9780784412770.032.

[5] Hagerty, D. Joseph, and Ralph B. Peck. "Heave and lateral movements due to pile driving." Journal of Soil Mechanics \& Foundations Div (1971): 1513- 1532.

[6] Attewell, P. B., and I. W. Farmer. "Modern Piling: Part Two-Attenuation of Ground Vibrations from Pile Driving." Ground engineering (1973): 26-29.

[7] Dowding, Charles H., and C. H. Dowding. Construction vibrations. Vol. 81. Upper Saddle River, NJ: Prentice Hall, 1996.

[8] Heckman, William S., and D. Joseph Hagerty. "Vibrations associated with pile driving." Journal of the Construction Division 104, no. 4 (1978): 385-394.

[9] Clough, G. Wayne, and Jean-Lou Chameau. "Measured effects of vibratory sheetpile driving." Journal of the Geotechnical Engineering Division 106, no. 10 (1980): 1081-1099.

[10] Massarsch, K. R. "Settlements and damage caused by construction-induced vibrations." In Proceedings of international workshop wave, pp. 299-315. 2000.

[11] Massarsch, K.R. \& Fellenius, B.H. "Ground Vibrations Induced by Impact Pile Driving". Proceedings of the 6th International Conference on Case Histories in Geotechnical Engineering, Arlington, August 11-16, 2008.

[12] Tavasoli, Omid, and Mahmoud Ghazavi. "Wave Propagation and Ground Vibrations Due to Non-Uniform Cross-Sections Piles Driving." Computers and Geotechnics 104 (December 2018): 13-21. doi:10.1016/j.compgeo.2018.08.010.

[13] Deckner, Fanny, Kenneth Viking, and Staffan Hintze. "Wave Patterns in the Ground: Case Studies Related to Vibratory Sheet Pile Driving.” Geotechnical and Geological Engineering 35, no. 6 (June 29, 2017): 2863-2878. doi:10.1007/s10706-017-0285-x.

[14] Sormeie, Amin, and Mahmoud Ghazavi. “Analysis of Non-Uniform Piles Driven into Cohesive Soils.” Soil Dynamics and Earthquake Engineering 109 (June 2018): 282-285. doi:10.1016/j.soildyn.2018.03.014.

[15] Doubrovsky, M.P., and G.N. Meshcheryakov. "Physical Modeling of Sheet Piles Behavior to Improve Their Numerical Modeling and Design.” Soils and Foundations 55, no. 4 (August 2015): 691-702. doi:10.1016/j.sandf.2015.06.003.

[16] Deckner, Fanny, Kenneth Viking, and Staffan Hintze. "Aspects of ground vibrations due to pile and sheet pile driving." Electronic Journal of Geotechnical Engineering 20, no. 19 (2015): 11161-11176. 
[17] Finno, Richard J.; Atmatzidis, Dimitrios K.; and Nerby, Steven M.,"Ground Response to Sheet Pile Installation in Clay" International Conference on Case Histories in Geotechnical Engineering. 34, 1988.

[18] Woods, Richard D. "Dynamic Effects of Pile Installations on Adjacent Structures.” Transportation Research Board, 1997.

[19] Khoubani, Ali, and Mohammad Mehdi Ahmadi. "Numerical Study of Ground Vibration Due to Impact Pile Driving." Proceedings of the Institution of Civil Engineers - Geotechnical Engineering 167, no. 1 (February 2014): 28-39. doi:10.1680/geng.11.00094.

[20] Athanasopoulos, G.A, and P.C Pelekis. "Ground Vibrations from Sheetpile Driving in Urban Environment: Measurements, Analysis and Effects on Buildings and Occupants.” Soil Dynamics and Earthquake Engineering 19, no. 5 (July 2000): $371-387$. doi:10.1016/s0267-7261(00)00008-7.

[21] Lamens, Pascale, Amin Askarinejad, Robbin W. Sluijsmans, and Antoine Feddema. "Ground Response during Offshore Pile Driving in a Sandy Slope.” Géotechnique (March 13, 2019): 1-11. doi:10.1680/jgeot.18.p.023.

[22] Wang, Jinfeng, Huawei Xiang, and Jianguo Yan. "Numerical Simulation of Steel Sheet Pile Support Structures in Foundation Pit Excavation." International Journal of Geomechanics 19, no. 4 (April 2019): 05019002. doi:10.1061/(asce)gm.19435622.0001373 .

[23] Grizi, Athina, Adda Athanasopoulos-Zekkos, and Richard D. Woods. "Ground Vibration Measurements Near Impact Pile Driving." Journal of Geotechnical and Geoenvironmental Engineering 142, no. 8 (August 2016): 04016035. doi:10.1061/(asce)gt.1943-5606.0001499. 